\title{
Mapping a Wild Tomato Introgression Associated with Tomato Yellow Leaf Curl Virus Resistance in a Cultivated Tomato Line
}

\author{
Peter M. Hanson \\ Asian Vegetable Research and Development Center, P.O. Box 42 Shanhua, Tainan, Taiwan 741 \\ Dario Bernacchi ${ }^{1}$ \\ Department of Plant Breeding and Biometry, 252 Emerson Hall, Cornell University, Ithaca, NY 14853-1902 \\ Sylvia Green \\ Asian Vegetable Research and Development Center, P.O. Box 42 Shanhua, Tainan, Taiwan 741 \\ Steven D. Tanksley \\ Department of Plant Breeding and Biometry, 252 Emerson Hall, Cornell University, Ithaca, NY 14853-1902
}

Venkataramappa Muniyappa and Attiganal S. Padmaja

Department of Plant Pathology, University of Agricultural Sciences, Bangalore GKVK-560 065, India

Huei-mei Chen, George Kuo, Denise Fang, and Jen-tzu Chen

Asian Vegetable Research and Development Center, P.O. Box 42 Shanhua, Tainan, Taiwan 741

\begin{abstract}
AdDitional INDEX WORDs. geminivirus, plant breeding, Lycopersicon sp.
Abstract. Tomato yellow leaf curl virus (TYLCV), a heterogeneous complex of whitefly-vectored geminiviruses, is a serious production constraint of tomato (Lycopersicon esculentum Mill.) in Asia, the Middle East, and the Americas. In this study we report on mapping of a DNA fragment introgressed into cultivated tomato presumably from the wild species $L$. hirsutum Humb. and Bonpl. and found to be associated with TYLCV resistance. To locate introgressions of wild tomato alleles in TYLCV-resistant tomato line H24, its DNA was digested with six restriction enzymes and probed with 90 RFLP markers evenly spaced throughout the genome. This polymorphism survey revealed the presence of one wild tomato introgression each on chromosomes 8 and 11. Plants of a $\mathrm{F}_{2}$ cross between $\mathrm{H} 24$ and a susceptible tomato line were probed with randomly amplified polymorphic DNA (RFLP) markers linked to the targeted regions and $F_{3}$ families were developed by selfpollination of $\mathrm{F}_{2}$ plants that carried none, one, or both introgressions in either homozygous or heterozygous states. Plants of $\mathrm{F}_{3}$ families, parents, and control tomato line Ty52 (homozygous for the $T y-1$ allele for TYLCV tolerance) were exposed to viruliferous whiteflies (Bemisia tabaci Gennadius) in greenhouses at the Asian Vegetable Research and Development Center, Taiwan, and the University of Agricultural Sciences, Bangalore, India. Results indicated that $F_{3}$ families homozygous for the introgression on chromosome 11 were resistant to TYLCV at both locations. Additional probing showed that the chromosome 11 introgression spanned markers TG36 to TG393, covering a distance of at least 14.6 centimorgans. This is the first report of TYLCV resistance in tomato mapped to chromosome 11.
\end{abstract}

Tomato yellow leaf curl virus (TYLCV) refers to a heterogeneous complex of geminiviruses (Czosnek and Laterrot, 1997) vectored by the whitefly, Bemisia tabaci, that infects tomato (Lycopersicon esculentum), pepper (Capsicum annuum L. var. annuum), potato (Solanum tuberosum L. ssp. tuberosum), tobacco (Nicotiana tabacum L.) and several dicot weed species (Green and Kalloo, 1994; Polston and Anderson, 1997; Ramappa et al., 1998). In tomato, disease symptoms include leaf curling and yellowing, and plant stunting; yield losses can reach $100 \%$ if plants are infected in early growth stages (Green and Kalloo, 1994; Picó et al., 1996).

TYLCV is a serious tomato production constraint in tropical and subtropical Asia (Green and Kalloo, 1994; Zeidan et al.,

Received for publication 29 Mar. 1999. Accepted for publication 26 Sept. 1999. Journal paper no. 162 of the Asian Vegetable Research and Development Center. We thank G. Kalloo, for providing seed of H24 tomato line, and the Taiwan Council of Agriculture for funding this project. The cost of publishing this paper was defrayed in part by the payment of page charges. Under postal regulations, this paper therefore must be hereby marked advertisement solely to indicate this fact.

${ }^{1}$ Current address: Dekalb Argentina S.A., Ruta Nacional 226, km 7, Mar del Plata (7600), Argentina.
1999). Symptoms of the disease were first described in India by Vasudeva and Samraj (1948). In the southern Indian state of Karnataka, the major tomato producing region in India, TYLCV can infect tomato crops throughout the year, although disease incidence is highest during the summer crop (February to May) when $100 \%$ incidence has been reported (Saikia and Muniyappa, 1989). In Taiwan, the disease has been detected in farmers' fields in all parts of the island (Asian Vegetable Research and Development Center, 1994) but infection is frequent in southern and central counties where tomato cultivation is common year-round close to fields of whitefly hosts such as watermelon [Citrullus lanatus (Thunb.) Matsum. \& Nakai], melon (Cucumis melo ssp. melo) and vegetable soybean [Glycine max (L.) Merr.]. Disease incidence is highest in the late dry season/early wet season (March to June) when high temperatures favor rapid growth of whiteflies. Few TYLCV-resistant tomato cultivars are available in Asia, and attempts by farmers to control the disease through frequent pesticide applications are often ineffective, contaminate the environment, and pose a health risk to themselves and consumers.

High levels of TYLCV resistance have been reported in 
certain accessions of several wild Lycopersicon species, including L. hirsutum, L. chilense Dun., L. pimpinellifolium (Jusl.) Mill., L. cheesmanii Riley, and L. peruvianum (L.) Mill. (Friedmann et al., 1998; Hassan et al., 1984; Kalloo and Banerjee, 1990; Kasrawi et al., 1988; Kasrawi and Mansour, 1994; Laterrot, 1992; Muniyappa et al., 1991; Pilowsky and Cohen, 1974; Scott et al., 1995; Vidavsky and Czosnek, 1998; Zakay et al., 1991). Introgression of TYLCV resistance alleles into cultivated tomato from the wild species started as early as 1974 (Pilowsky and Cohen, 1990) and was completed successfully by several researchers (Friedmann et al., 1998; Kalloo and Banerjee, 1990; Kasrawi et al., 1988; Laterrot, 1992; Scott et al., 1995; Vidavsky and Czosnek, 1998; Zamir et al., 1994). A single partially dominant gene for TYLCV tolerance, $T y$-1, was introgressed into tomato from L. chilense accession LA1969 (Zamir et al., 1994). In India, Kalloo and Banerjee (1990) developed six TYLCVresistant tomato lines with resistance derived from L. hirsutum $\mathrm{f}$. glabratum accession 'B 6013'. One of these lines, H24, has shown excellent TYLCV resistance in Taiwan (Green, unpublished data) and south India (Muniyappa, unpublished data). Therefore, the objective of this study was to map TYLCV resistance factors in $\mathrm{H} 24$ and to determine their relationship to other mapped TYLCV resistance genes.

\section{Materials and Methods}

TYLCV resistance in $\mathrm{H} 24$ is reported to have originated from L. hirsutum f. glabratum accession 'B6013' (Kalloo and Banerjee, 1990); additional information about B6013 such as the collection site, date of collection, and other passport data are unknown or not available. Line $\mathrm{H} 24$ was selected from a population that had undergone four backcrosses to L. esculentum TYLCV-susceptible recurrent parent 'Hisar Arun' (Hisar Arun=Sel-7), followed by two generations of inbreeding (Kalloo and Banerjee, 1990; Kalloo and Bhutani, 1993). We hypothesized that the H24 genome retained a few wild tomato fragments in an otherwise $L$. esculentum background, and that these fragments putatively controlled TYLCV resistance. We carried out a three step process to test this hypothesis: 1) localization of wild tomato introgressions in $\mathrm{H} 24 ; 2$ ) use of restricted fragment length polymorphism (RFLP) markers linked to the putative resistance factors to select $\mathrm{F}_{2: 3}\left(\mathrm{~F}_{3}\right)$ families from a segregating population with single or combined introgressions; 3 ) TYLCV screening of the $\mathrm{F}_{3}$ families to confirm the effects of $L$. hirsutum introgressions on TYLCV resistance.

LOCATION OF INTROGRESSIONS IN H24. The genomes of TYLCVresistant tomato inbred line $\mathrm{H} 24$ and a TYLCV-susceptible AVRDC inbred tomato line CL5915-93D 4 -1-0-3 (CL5915) were surveyed with RFLP markers and compared for polymorphism. RFLP analysis can easily detect wild tomato alleles in a $L$. esculentum background (Chunwongse et al., 1994; Miller and Tanksley, 1990; Young and Tanksley, 1989), though in rare instances polymorphisms betweeen $L$. esculentum sources can also be detected (Miller and Tanksley, 1990). To address this limitation, all polymorphic regions were considered potentially associated with TYLCV resistance.

Plants of H24 and CL5915 were grown in a greenhouse at Cornell University, and DNA was extracted according to the methods described by Bernacchi and Tanksley (1997). DNA samples were digested with restriction enzymes HindIII, EcoRV, $X b a \mathrm{I}, S c a \mathrm{I}, E c o$ RI, and Bst NI and probed with 90 mapped RFLP markers spaced evenly throughout the genome. A total of 15 replicate filters were made containing the samples for each of the six restriction enzymes.

IDENTIFICATION OF $\mathrm{F}_{2} / \mathrm{F}_{3}$ FAMILIES WITH SPECIFIC INTROGRESSIONS FROM H24. Genotypes to study the effects of different H24 introgressions on TYLCV resistance were developed by probing an $\mathrm{F}_{2}$ population from the cross of CL5915 (susceptible) x H24 (resistant) with RFLP markers showing polymorphism between CL5915 and $\mathrm{H} 24$. A total of $168 \mathrm{~F}_{2}$ seedlings were grown in 72-hole trays, under artificial illumination, and subjected to DNA extraction $30 \mathrm{~d}$ after sowing. DNA from the $\mathrm{F}_{2}$ plants was digested, electrophoresed, blotted, and probed with markers corresponding to the two polymorphic regions described previously. Selected $\mathrm{F}_{2}$ plants with specific genotypic configurations were transplanted to the greenhouse into larger pots, and self-pollinated manually to produce $\mathrm{F}_{3}$ seed.

TylCV SCREENING. A total of 22 entries, including $19 \mathrm{~F}_{3}$ families, two parents, and TYLCV-tolerant control line Ty52 (homozygous for the $T y-1$ allele for TYLCV tolerance) were tested for TYLCV reactions at the University of Agricultural Sciences (UAS), Bangalore, India and the Asian Vegetable Research and Development Center(AVRDC), Shanhua, Taiwan. At UAS, TYLCV strains were cultured on plants of susceptible tomato cultivars Arkavikas or Rashmi. Before inoculation, whitefly adults were collected from healthy cotton plants (Gossypium hirsutum L.) of the cultivar Laxmi (nonhost of TYLCV) and placed on TYLCV-infected tomato plants for $24 \mathrm{~h}$ to acquire the virus. Tomato seedlings 10 to $15 \mathrm{~d}$ old were inoculated individually with 10 to 15 viruliferous whiteflies and each plant was covered with plastic or polyvinyl chloride tubes for $48 \mathrm{~h}$. Entries were not replicated and each included 36 plants, except for $\mathrm{H} 24$ and Ty 52 which had 48 and 23 plants, respectively. Parental lines and Ty 52 were sown and inoculated about $15 \mathrm{~d}$ after respective sowing and inoculation dates of the $\mathrm{F}_{3}$ families. Inoculated seedlings were kept in the greenhouse and evaluated for disease incidence at $3,6,9$, and 11 weeks after whitefly exposure. Disease incidence was determined as the percentage of symptomatic plants in each entry. Symptom severity for each entry was rated as described by Muniyappa et al. (1991): none; mild (light yellowing along the leaf margins); moderate (slight plant stunting, and foliar yellowing and curling); and severe (very severe plant stunting, and leaf size reduction, leaf curling and yellowing).

At the AVRDC, tomato seedlings were grown in 72-cell seedling trays $(12 \times 6$ cells, cell volume $=65 \mathrm{~mL})$. An experimental unit included 12 plants (two adjacent rows of six plants) grown on the same tray. Experimental units were arranged in a randomized complete block design with two replications. Subsequently, the 12-d-old seedlings were moved to a netted screen house and each tray was placed on a bench and surrounded on three sides by TYLCV-infected tomato plants (cultivar TK70) infested with whiteflies. Disease incidence and symptom severity were evaluated as at UAS. AVRDC TYLCV incidence data were analyzed as a randomized complete block design using the General Linear Model (PROC GLM) procedure of the SAS (SAS Institute Inc., Cary, N.C.). Entry means at AVRDC were separated by the Waller-Duncan test $(k=100)$. Comparison of $\mathrm{F}_{3}$ genotypic group means was carried out by unpaired $t$ tests.

Parental lines, Ty52, and four resistant $\mathrm{F}_{3}$ families were sampled 11 weeks after inoculation and tested for TYLCV infection by dot blot hybridization. Leaf disks $\approx 1 \mathrm{~cm}$ in diameter were squashed onto nylon membranes. After denaturation and neutralization, the membranes were treated with $2 \times$ sodium chloride and sodium citrate (SSC). After fixing the nucleic acid to the membrane, the membranes were treated with prehybridization solution for $1 \mathrm{~h}$ at $65^{\circ} \mathrm{C}$ for hybridizationand then were 
incubated overnight at $65^{\circ} \mathrm{C}$ with a digoxigenin-labeled DNA probe. Membranes were washed twice with $2 \times \mathrm{SSC}[0.1 \%$ sodium dodecyl sulfate (SDS)] for $5 \mathrm{~min}$ at room temperature and $0.1 \times \operatorname{SSC}(0.1 \% \mathrm{SDS})$ for $15 \mathrm{~min}$ at $65^{\circ} \mathrm{C}$. Digoxigenin detection was carried out according to the supplier's (Roche Molecular Biochemicals, Mannheim, Germany) instructions.

Leaf samples from the AVRDC experiment screening were probed with a $1.5 \mathrm{~kb}$ DNA-A probe of TYLCV-TW (GenBank No. U88692). Samples from UAS were first probed with a $1.5 \mathrm{~kb}$ probe of TYLCV-SL (Sri Lanka) which shares a 94\% sequence homology with, and is regarded as an isolate of TYLCV-Ban2 (GenBank No. Z48182). After probing with TYLCV-SL, membranes from UAS were subsequently probed with a $1.5 \mathrm{~kb}$ DNA-A probe of TYLCVBan3 (GenBank No. U38239). TYLCV-Ban2 and TYLCV-Ban3 are geminiviruses isolated from infected tomato plants in the Bangalore area of south India and identified in previous samples of TYLCV-infected tomato samples from UAS.

\section{Results}

Polymorphic Regions BetWeEn TYLCV-RESISTANT AND TYLCVSUSCEPTIBLE PARENTS. Analysis of the 90 RFLP loci assayed revealed polymorphisms between H24 and CL5915 for marker TG302 on chromosome 8, and markers TG36 and TG393 on chromosome 11. These two introgressions in $\mathrm{H} 24$ were associated putatively with
TYLCV resistance. Both regions were homozygous in $\mathrm{H} 24$ for the wild tomato introgression as shown by the absence of the corresponding L. esculentum allele, which if still segregating, would have appeared in the bulk DNA preparation.

TYlCV REACTIONS. The percentage of symptomatic plants 6 and 11 weeks after inoculation and symptom severity of parental lines CL5915 and H24, tolerant control Ty52 and $19 \mathrm{~F}_{3}$ families, evaluated at UAS and AVRDC, are presented in Table 1. Following 11 weeks of exposure to viruliferous whiteflies, almost all plants of susceptible parent CL5915 had developed severe stunting, foliar yellowing, and curling symptoms at both locations. No symptoms were observed on $\mathrm{H} 24$ at AVRDC. At UAS, slightly more than half the $\mathrm{H} 24$ plants developed mild (light foliar yellowing) or moderate (foliar yellowing and curling and slight plant stunting) by 11 weeks after exposure. Disease incidence of TYLCV-tolerant control Ty52 (homozygous for the TYLCV tolerance allele, $T y-1$ ) was $52 \%$ at UAS and $36 \%$ at AVRDC; symptom severity on symptomatic Ty52 plants was moderate or severe.

Production and testing of Selected $F_{3}$ Families. After detecting polymorphism between H24 and CL5915 at two genomic regions, $168 \mathrm{~F}_{2}$ seedlings derived from the cross CL5915 x H24 were probed with TG302, TG36, and TG393. Nineteen $F_{2}$ plants were selected on the basis of their RFLP genotypes (Table 1) and self-pollinated in the greenhouse to produce $F_{3}$ families for TYLCV screening. Based on disease reactions at UAS and AVRDC,

Table 1. Percentage of symptomatic plants and symptom severity of $\mathrm{F}_{3}$ families, parental lines, and Ty52 after inoculation with tomato yellow leaf curl viruses at the University of Agricultural Sciences (UAS), Bangalore, India, and the Asian Vegetable Research and Development Center (AVRDC), Taiwan.

\begin{tabular}{|c|c|c|c|c|c|c|c|c|}
\hline \multirow[b]{4}{*}{ Entry } & \multirow{2}{*}{\multicolumn{2}{|c|}{ RFLP $^{z}$}} & \multicolumn{3}{|c|}{ UAS } & \multicolumn{3}{|c|}{ AVRDC } \\
\hline & & & \multirow{2}{*}{\multicolumn{2}{|c|}{$\begin{array}{c}\text { Weeks after } \\
\text { exposure }\end{array}$}} & \multirow{3}{*}{$\begin{array}{l}\text { Symptom } \\
\text { severity }^{y}\end{array}$} & \multirow{2}{*}{\multicolumn{2}{|c|}{$\begin{array}{c}\text { Weeks after } \\
\text { exposure }\end{array}$}} & \multirow{3}{*}{$\begin{array}{l}\text { Symptom } \\
\text { severity }^{y}\end{array}$} \\
\hline & \multirow[b]{2}{*}{ TG302 } & \multirow{2}{*}{$\begin{array}{l}\text { TG36/ } \\
\text { TG393 }\end{array}$} & & & & & & \\
\hline & & & 6 & 11 & & 6 & 11 & \\
\hline F3-77 & $\mathrm{EE}$ & $\mathrm{EE}$ & 83 & 100 & Severe & $75 a b^{x}$ & $95 \mathrm{a}$ & Severe \\
\hline F3-7 & $\mathrm{EH}$ & $\mathrm{EE}$ & 75 & 100 & Severe & $79 \mathrm{ab}$ & $100 \mathrm{a}$ & Severe \\
\hline F3-49 & EH & $\mathrm{EE}$ & 94 & 100 & Severe & $76 \mathrm{ab}$ & $88 \mathrm{a}$ & Severe \\
\hline F3-31 & EH & $\mathrm{EE}$ & 97 & 97 & Severe & $58 \mathrm{~b}$ & $88 \mathrm{a}$ & Severe \\
\hline F3-6 & $\mathrm{HH}$ & $\mathrm{EE}$ & 69 & 100 & Severe & $83 \mathrm{a}$ & $100 \mathrm{a}$ & Severe \\
\hline F3-19 & $\mathrm{HH}$ & $\mathrm{EE}$ & 92 & 100 & Severe & $63 \mathrm{ab}$ & $88 \mathrm{a}$ & Severe \\
\hline F3-53 & $\mathrm{HH}$ & $\mathrm{EE}$ & 75 & 100 & Severe & $83 \mathrm{a}$ & $100 \mathrm{a}$ & Severe \\
\hline F3-3 & $\mathrm{EE}$ & $\mathrm{EH}$ & 58 & 94 & Segregating & $10 \mathrm{~cd}$ & $5 \mathrm{fg}$ & Segregating \\
\hline F3-75 & $\mathrm{EE}$ & $\mathrm{EH}$ & 44 & 52 & Segregating & $28 \mathrm{c}$ & $46 \mathrm{~b}$ & Segregating \\
\hline F3-4 & $\mathrm{EH}$ & $\mathrm{EH}$ & 31 & 86 & Segregating & $25 \mathrm{c}$ & $33 \mathrm{~b}-\mathrm{d}$ & Segregating \\
\hline F3-55 & $\mathrm{EH}$ & $\mathrm{EH}$ & 17 & 28 & Segregating & $17 \mathrm{~cd}$ & $26 \mathrm{c}-\mathrm{e}$ & Segregating \\
\hline F3-79 & $\mathrm{HH}$ & $\mathrm{EH}$ & 22 & 39 & Segregating & $13 \mathrm{~cd}$ & $15 \mathrm{e}-\mathrm{g}$ & Segregating \\
\hline F3-114 & $\mathrm{EE}$ & $\mathrm{EH}$ & 14 & 25 & Mild & $13 \mathrm{~cd}$ & $0 \mathrm{~g}$ & None \\
\hline F3-123 & EH & EH & 36 & 42 & Segregating & $17 \mathrm{~cd}$ & $17 \mathrm{~d}-\mathrm{f}$ & Segregating \\
\hline F3-50 & EH & $\mathrm{HH}$ & 6 & 19 & Mild & $0 \mathrm{~d}$ & $0 \mathrm{~g}$ & None \\
\hline F3-24 & $\mathrm{EE}$ & $\mathrm{HH}$ & 8 & 36 & Mild & $0 \mathrm{~d}$ & $0 \mathrm{~g}$ & None \\
\hline F3-99 & $\mathrm{EE}$ & $\mathrm{HH}$ & 8 & 33 & Mild & $0 \mathrm{~d}$ & $0 \mathrm{~g}$ & None \\
\hline F3-90 & HH & $\mathrm{HH}$ & 3 & 33 & Mild & $0 \mathrm{~d}$ & $0 \mathrm{~g}$ & None \\
\hline F3-91 & $\mathrm{HH}$ & $\mathrm{HH}$ & 3 & 17 & Mild & $0 \mathrm{~d}$ & $0 \mathrm{~g}$ & None \\
\hline $\mathrm{H} 24$ & $\mathrm{HH}$ & $\mathrm{HH}$ & 16 & 57 & Mild & $0 \mathrm{~d}$ & $0 \mathrm{~g}$ & None \\
\hline CL5915 & $\mathrm{EE}$ & $\mathrm{EE}$ & 94 & 94 & Severe & $65 \mathrm{ab}$ & $94 \mathrm{a}$ & Severe \\
\hline $\mathrm{Ty} 52^{\mathrm{w}}$ & --- & --- & 19 & 52 & Moderate/severe & $25 \mathrm{c}$ & $36 \mathrm{bc}$ & Moderate \\
\hline
\end{tabular}

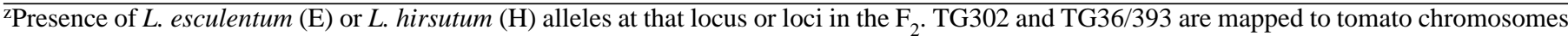
8 and 11 , respectively.

ySymptom severity: mild = light yellowing along leaf margins but no curling; moderate = foliar yellowing and curling, slight plant stunting; severe = severe leaf curling and puckering, and plant stunting; segregating = individual plants showing mild, moderate, or severe symptoms.

${ }^{\mathrm{x}}$ Mean separation in columns by Waller-Duncan test $(k=100)$.

wTy52 is homozygous for the Ty-1 allele for TYLCV tolerance (Zamir et al., 1994) 
Table 2. Mean percentage of TYLCV-infected plants of $\mathrm{F}_{3}$ genotypic groups classified according to RFLP markers TG36/TG393, and $t$ test comparisons.

\begin{tabular}{|c|c|c|c|c|c|}
\hline \multirow[b]{3}{*}{ Genotype $^{y}$} & \multirow[b]{3}{*}{$\mathrm{n}$} & \multicolumn{2}{|c|}{$\mathrm{UAS}^{\mathrm{z}}$} & \multicolumn{2}{|c|}{ AVRDC } \\
\hline & & \multicolumn{2}{|c|}{ Weeks after exposure } & \multicolumn{2}{|c|}{ Weeks after exposure } \\
\hline & & 6 & 11 & 6 & 11 \\
\hline$\overline{\mathrm{EE}}$ & 7 & 83.6 & 99.6 & 73.9 & 94.1 \\
\hline $\mathrm{EH}$ & 7 & 31.7 & 52.3 & 17.6 & 20.3 \\
\hline \multirow[t]{2}{*}{$\mathrm{HH}$} & 5 & 5.6 & 27.6 & 0 & 0 \\
\hline & & \multicolumn{4}{|c|}{ Difference } \\
\hline \multicolumn{6}{|l|}{$t$ test } \\
\hline EE vs. HH & & $78.0^{* *}$ & $72.0^{* *}$ & $73.9^{* *}$ & $94.1^{* * *}$ \\
\hline EE vs. EH & & $51.9^{*}$ & $47.3^{*}$ & $56.3^{*}$ & $73.8^{* * *}$ \\
\hline EH vs. HH & & $26.1^{\mathrm{NS}}$ & $24.7^{\mathrm{NS}}$ & $17.6^{\mathrm{NS}}$ & $20.3^{\mathrm{NS}}$ \\
\hline
\end{tabular}

$\overline{{ }^{\mathrm{z}} \mathrm{UAS}}=$ University of Agricultural Sciences, Bangalore, India; AVRDC = Asian Vegetable Research and Development Center, Taiwan. yPresence of L. esculentum (E) or L. hirsutum $(\mathrm{H})$ alleles at TG36/TG393 in the $\mathrm{F}_{2}$. TG36 and TG393 were mapped to tomato chromosome 11. ss, ${ }^{* * * *}$ Nonsignificant or significant at $P=0.05$ or 0.01 , respectively, by unpaired $t$ test.

it was possible to classify the families into three groups. One group, consisting of the five, $\mathrm{F}_{3}$ families homozygous for the chromosome 11 introgression $\left(\mathrm{F}_{3}-50, \mathrm{~F}_{3}-24, \mathrm{~F}_{3}-99, \mathrm{~F}_{3}-90, \mathrm{~F}_{3}-91\right)$, was highly resistant to TYLCV-TW in the AVRDC trial, remained symptomless throughout the experiment, and were not significantly different than H24. At UAS, where virus strains TYLCV-SL (closely related to TYLCV-Ban2) and TYLCV-Ban3 were present, mild symptoms were observed on some plants in each of the above $\mathrm{F}_{3}$ families and disease incidence at week 11 ranged from $17 \%$ to $36 \%$, and the group mean was $27.6 \%$ (Table 2). The average disease incidence of $\mathrm{F}_{3}$ families 90 and 91 , homozygous for both introgressions, was $25 \%$ at UAS, compared to the average TYLCV incidence of $31 \%$ for the three families homozygous for the chromosome 11 introgression but lacking the chromosome 8 introgression. This last result would indicate that the chromosome 8 introgression did not greatly enhance TYLCV resistance at UAS.

A second group, consisting of the seven $\mathrm{F}_{3}$ families lacking the chromosome 11 introgression $\left(F_{3}-77, F_{3} 7, F_{3}-49, F_{3}-31, F_{3}-6, F_{3}-19\right.$, and $\mathrm{F}_{3}-53$ ) developed high TYLCV incidences and severe symptoms by week 6 after whitefly exposure. Eleven weeks after exposure, incidences ranged from $97 \%$ to $100 \%$ at UAS and $88 \%-100 \%$ at AVRDC. At both UAS and the AVRDC, mean TYLCV incidences 11 weeks after exposure of $\mathrm{F}_{3}$ families lacking the chromosome 11 introgression ( $99.6 \%$ and $94.1 \%$, respectively) were sig- nificantly greater $(P=0.01)$ than the mean of those families homozygous for the chromosome 11 introgression (27.6\% and $0 \%$, respectively) according to $t$ tests (Table 2). Symptoms on the above families were severe and like those of the susceptible parent, CL5915.

The third group included the seven $\mathrm{F}_{3}$ families $\left(\mathrm{F}_{3}-3, \mathrm{~F}_{3}-4, \mathrm{~F}_{3}-75\right.$, $\mathrm{F}_{3}-55, \mathrm{~F}_{3}-79, \mathrm{~F}_{3}-114$, and $\mathrm{F}_{3}-123$ ) derived from $\mathrm{F}_{2}$ plants heterozygous for the chromosome 11 introgression. Self-pollination of these $\mathrm{F}_{2}$ plants would have resulted in $\mathrm{F}_{3}$ families segregating in the expected ratio of $1 \mathrm{HH}$ (homozygous for the wild tomato introgression): $2 \mathrm{EH}$ (heterozygous) : $1 \mathrm{EE}$ (homozygous for L. esculentum alleles). If resistance is completely dominant, about $25 \%$ of the plants would be expected to develop symptoms, while if resistance is recessive, about $75 \%$ of the plants in these families would be susceptible.

Dot blot hybridization tests of CL5915 plants sampled at the AVRDC tested positive for infection by TYLCV-TW (Table 3 ). Resistant parent $\mathrm{H} 24$ tested negative for infection by TYLCV$\mathrm{TW}$, indicating the virus was not present in the samples or virus titer was too low for dot blot detection. About $20 \%$ of the Ty52 samples tested positive for TYLCV-TW. Samples taken from $\mathrm{F}_{3}-$ $24, \mathrm{~F}_{3}-99, \mathrm{~F}_{3}-114, \mathrm{~F}_{3}-90$, and $\mathrm{F}_{3}-9111$ weeks after exposure also tested negative for TYLCV-TW. At UAS, almost all CL5915 samples were coinfected by TYLCV-SL and TYLCV-Ban3. Of

Table 3. Nucleic acid hybridization test results of parental lines, TY52, and selected $\mathrm{F}_{3}$ families for TYLCV infection at the University of Agricultural Sciences (UAS), Bangalore, India, and the Asian Vegetable Research and Development Center (AVRDC), Taiwan.

\begin{tabular}{|c|c|c|c|c|c|c|}
\hline \multirow[b]{3}{*}{ Entry } & \multicolumn{4}{|c|}{ UAS } & \multicolumn{2}{|c|}{ AVRDC } \\
\hline & \multirow{2}{*}{$\begin{array}{c}\text { Samples } \\
\text { (no.) }\end{array}$} & \multicolumn{3}{|c|}{ No. positive } & \multirow{2}{*}{$\begin{array}{c}\text { Samples } \\
\text { (no.) }\end{array}$} & \multirow{2}{*}{$\frac{\text { No. positive }}{\text { TW }}$} \\
\hline & & $\mathrm{SL}^{\mathrm{z}}$ & Ban3 & Both & & \\
\hline$\overline{\mathrm{H}} 24$ & 44 & 0 & 16 & 2 & 10 & 0 \\
\hline CL5915 & 9 & 1 & 0 & 7 & 10 & 10 \\
\hline Ту52 & 21 & 10 & 1 & 1 & 10 & 2 \\
\hline F3-24 & 9 & 0 & 0 & 0 & 7 & 0 \\
\hline F3-50 & 11 & 2 & 2 & 2 & $\mathrm{NT}^{\mathrm{y}}$ & --- \\
\hline F3-55 & 10 & 3 & 1 & 2 & NT & --- \\
\hline F3-79 & 6 & 1 & 1 & 1 & NT & --- \\
\hline F3-90 & 5 & 1 & 1 & 2 & 8 & 0 \\
\hline F3-91 & 8 & 4 & 1 & 1 & 10 & 0 \\
\hline F3-99 & 5 & 0 & 2 & 1 & 8 & 0 \\
\hline
\end{tabular}

${ }^{\mathrm{z} S L}=\mathrm{TYLCV}-\mathrm{SL}$, Ban 3 = TYLCV-Ban3, and TW $=$ TYLCV-Taiwan.

${ }^{\mathrm{N} T}=$ not tested. 
the virus-positive $\mathrm{H} 24$ samples, most were infected with TYLCVBan3 while most of the virus-positive Ty52 samples at UAS were infected with TYLCV-SL. Except for $\mathrm{F}_{3}-24$, virus-positive samples were found in each of the $\mathrm{F}_{3}$ families tested.

Chromosome 11 introgression size. To estimate the size of the introgression on chromosome 11 in more detail, DNA of resistant parent $\mathrm{H} 24$ and susceptible parent CL5915 were cut with 13 restriction enzymes and probed with additional markers mapping to chromosome 11. This introgression spanned the region from TG393 to TG36, a distance of at least 14.6 centimorgans (cM) (Fig. 1). The introgression ends between TG36 and CT107C on the centromere side and may extend beyond TG393 on the telomeric end of the chromosome.

\section{Discussion}

TYLCV resistance in $\mathrm{H} 24$ was mapped by locating its wild tomato introgressions via an RFLP survey, followed by tests of $F_{3}$ families representing all possible combinations of the detected polymorphisms. We succeeded because: 1) wild tomato introgressions in a L. esculentum background can be identified by RFLP; 2) introgressed TYLCV resistance in $\mathrm{H} 24$ was fixed stably by selection and inbreeding, which also resulted in elimination of unlinked wild tomato DNA; 3) 'Hisar Arun', the recurrent parent used to develop $\mathrm{H} 24$ apparently did not carry introgressions from wild tomato; and 4) no polymorphisms could be detected between the L. esculentum components of CL5915 and H24.

Results indicate that a wild tomato DNA fragment, presumably from L. hirsutum, introgressed into chromosome 11 of tomato inbred line H24, contains at least one gene conditioning TYLCV resistance or tolerance. Banerjee and Kalloo (1987) studied inheritance of TYLCV resistance in L. hirsutum accession B6013 and concluded that two genes acting epistatically conditioned resistance. We did not detect a second TYLCV resistance gene and it is possible that during the backcrossing process, $\mathrm{H} 24$ received only one major resistance gene from B6013. Presence of the chromosome 11 fragment was associated with a high level of resistance to the geminiviruses used in this study and it should be useful in development of TYLCV-resistant tomato cultivars in regions where the geminiviruses used in this study or related geminiviruses are present. We observed differences in the degree of resistance between AVRDC and UAS trials. $\mathrm{H} 24$ and the six $\mathrm{F}_{3}$ families homozygous for the chromosome 11 introgression were symptomless 11 weeks after inoculation at the AVRDC, and none of the plants sampled from these $\mathrm{F}_{3}$ families tested virus-positive for TYLCV-TW infection by dot blot hybridization. In the UAS trial, about half of the $\mathrm{H} 24$ plants developed slight yellowing along the leaf margins 11 weeks after inoculation, and $38 \%$ of $\mathrm{H} 24$ plants tested positive for infection by TYLCV-SL, TYLCV-Ban3, or both. Symptomatic plants in $\mathrm{F}_{3}$ families homozygous for the chromosome 11 introgression ranged from $17 \%$ to $36 \%$. In summary, resistance to TYLCV-TW approached immunity while resistance to TYLCV-SL and TYLCV-Ban3 acted more as tolerance, similar to the expression of $T y-1$ (Zamir et al., 1994). It would appear that gene action for resistance to TYLCV-TW is completely or partially dominant because TYLCV incidence of the seven heterozygous $\mathrm{F}_{3}$ families ranged from $0 \%$ to $46 \%$ with a group mean of $20.3 \%$. Disease incidence of the seven heterozygous $\mathrm{F}_{3}$ families at UAS ranged from $25 \%$ to $94 \%$ at 11 weeks after exposure. Because more than half the plants of resistant parent $\mathrm{H} 24$ showed symptoms, it is difficult to estimate the gene action for TYLCV resistance at UAS.

Entries were not tested for reaction to the TYLCV-TW, TYLCV-SL, and TYLCV-Ban3 in the same experiment under similar environmental conditions; consequently, it is not possible to determine whether differences in expression of resistance between locations were due to differences in environment, geminiviruses, or whitefly populations. At both locations, seedlings of entries were exposed to viruliferous whiteflies in the greenhouse. However, at UAS each seedling was caged with 10 whiteflies, while at the AVRDC a mass inoculation technique was used and very likely inoculum pressure was less than at UAS. Picó et al. (1998) found that whitefly inoculation technique affected expression of TYLCV resistance and high inoculum pressure reduced the level of TYLCV resistance. Genetic variation between geminiviruses at AVRDC and UAS may also have affected resistance. TYLCV-TW, TYLCV-SL, and TYLCVBan3 are all monopartite geminiviruses, and in that regard are similar to the tomato-infecting geminiviruses that predominate in the Mediterranean region (Czosnek and Laterrot, 1997). The TYLCV-TW replicase gene $(\mathrm{C} 1)$ and coat protein gene (V1) share sequence homologies of $82.1 \%$ and $77.0 \%$, respectively, with those of TYLCV-Ban3. Replicase gene and coat protein gene sequence homologies between TYLCV-TW and TYLCVSL have not yet been determined. However, TYLCV-Ban2, closely related to TYLCV-SL, has common C1 and V1 sequence homologies of $79.1 \%$ and $73.4 \%$, respectively, with TYLCV-TW (Green, unpublished data). Taxonomically, TYLCV-TW would be considered a different virus species from TYLCV-Ban3 and TYLCV-Ban2 (Czosnek and Laterrot, 1997; Padidam et al., 1995; Polston and Anderson, 1997).

This is the first report of TYLCV resistance in tomato mapped on chromosome 11. TYLCV resistance originating from $L$. chilense accession LA1969 (Zamir et al., 1994), L. pimpinellifolium hirsute INRA (Chagué et al., 1997), L. cheesmanii (Chagué et al., 1997), and L. chilense accessions LA1932 and LA 1938 (Griffiths and Scott, 1998) have been mapped to chromosome 6. Existence of a region of major TYLCV resistance genes on chromosome 6 has been suggested (Chagué et al., 1997). The chromosome 11 introgression identified in this experiment is longer than $14 \mathrm{cM}$ and, consequently, we cannot rule out the possibility that more than one TYLCV resistance

\section{Chromosome 11}

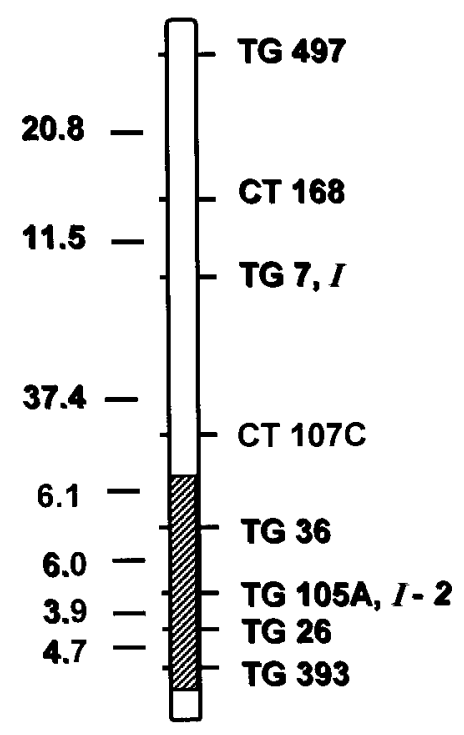

locus resides on this fragment. Additional fine-mapping will be required to determine the number and location of TYLCV resistance loci. Fine-mapping would be helpful to determine the distance of TYLCV resistance loci from the Immunity-2 (I-2) locus for resistance to race 2 of the fusarium wilt pathogen [Fusarium

Fig. 1. Location of the introgression associated with TYLCV resistance on tomato chromosome 11. Distances between markers are shown in Kosambi cM units. Loci $I$ (Immunity) and I-2 (Immunity2) condition resistances to races 1 and 2, respectively, of Fusarium oxysporum f. sp. lycopersici, the causal agent of tomato fusarium wilt. 
oxysporum f. sp. lycopersici (Sacc.) Snyder \& Hansen] and linked to TG105A (Tanksley et al. 1992). The chromosome 11 introgression overlaps $I-2$ and carries an allele for susceptibility to fusarium wilt race 2 . Because fusarium wilt and TYLCV are tropical tomato production constraints, it would be advantageous for tomato cultivars to possess both fusarium wilt and TYLCV resistance.

Ty52, a tomato inbred line homozygous for $T y-1$ (Zamir et al., 1994) for TYLCV tolerance, was not as resistant as H24 in our trials but clearly superior to CL5915 and other susceptible entries. Ty- 1 originated from L. chilense accession LA 1969 (Zamir et al., 1994) and conditions tolerance to the Israeli geminivirus, TYLCVISR. Pyramiding Ty- 1 and the chromosome 11 introgression identified in this study might broaden resistance against a wider range of geminiviruses or improve the degree of resistance or tolerance (Polston and Anderson, 1997). In this study, the two resistances seemed to complement each other: Ty52 plants showed less infection by TYLCV-SL than H24, while H24 seemed to demonstrate greater tolerance to TYLCV-Ban3 compared to Ty52. These results need confirmation screening with pure cultures of these virus isolates but they may indicate potential benefits of combining these resistance genes. Molecular markers would facilitate pyramiding TYLCV resistance genes at the AVRDC because it would be difficult to distinguish individuals carrying just the chromosome 11 introgression from individuals with both genes based on reaction to TYLCV-TW.

\section{Literature cited}

Asian Vegetable Research and Development Center. 1994. Progress report. Asian Veg. Res. Dev. Ctr., Shanhua, Taiwan.

Banerjee, M.K. and Kalloo. 1987. Inheritance of tomato leaf curl virus resistance in Lycopersicon hirsutum f. glabratum. Euphytica 36:581584.

Bernacchi, D. and S.D. Tanksley. 1997. An interspecific backcross of Lycopersicon esculentum $\times$ L. hirsutum: Linkage analysis and a QTL study of sexual incompatibility factors and floral traits. Genetics 147:861877.

Chagué V., J.C. Mercier, M. Guénard, A. de Courcel, and F. Vedel. 1997. Identification of RAPD markers linked to a locus involved in quantitative resistance to TYLCV in tomato by bulked segregant analysis. Theor. Appl. Genet. 95:671-677.

Chunwongse, J., T.B. Bunn, C. Crossman, J. Jiang, and S.D. Tanksley. 1994. Chromosomal localization and molecular-marker tagging of the powdery mildew resistance gene $(L v)$ in tomato. Theor. Appl. Genet. 89:76-79.

Czosnek, H. and H. Laterrot. 1997. A worldwide survey of tomato yellow leaf curl viruses. Arch. Virol. 142:1391-1406.

Friedmann, M., M. Lapidot, S. Cohen, and M. Pilowsky. 1998. A novel source of resistance to tomato yellow leaf curl virus exhibiting a symptomless reaction to viral infection. J. Amer. Soc. Hort. Sci. 123:1004 1007.

Green, S.K. and G. Kalloo. 1994. Leaf curl and yellowing viruses of pepper and tomato: An overview. Asian Veg. Res. Dev. Ctr., Shanhua, Taiwan. Tech. Bul. 21.

Griffiths, P.D. and J.W. Scott. 1998. Identification of molecular markers linked to tomato mottle virus resistance genes. HortScience 33:515.

Hassan, A.A., H.M. Mazayd, S.E. Moustafa, S.H. Nassar, M.K. Nakhla, and W.L. Sims. 1984. Inheritance of resistance to tomato yellow leaf curl virus derived from Lycopersicon cheesmanii and Lycopersicon hirsutum. HortScience 19:574-575.

Kalloo, G. and M.K. Banerjee. 1990. Transfer of tomato leaf curl virus resistance from Lycopersicon hirsutum f. glabratum to L. esculentum. Plant Breeding 105:156-159.

Kalloo, G. and R.D. Bhutani. 1993. Improvement of tomato, p. 45-68. In: K.L. Chadha and G. Kalloo (eds.). Advances in horticulture. vol. 5. Vegetable crops. Malhotra Publishing House, New Delhi, India.
Kasrawi, M.A. and A. Mansour. 1994. Genetics of resistant to tomato yellow leaf curl virus in tomato. J. Hort. Sci. 69:1095-1100.

Kasrawi, M.A., M.A. Suwwan, and A. Mansour. 1988. Sources of resistance to tomato-yellow-leaf curl-virus (TYLCV) in Lycopersicon species. Euphytica 37:61-64.

Laterrot, H. 1992. Resistance genitors to tomato yellow leaf curl virus (TYLCV). Tomato Leaf Curl Nswl. 1:2-4.

Miller, J.C. and S.D. Tanksley. 1990. RFLP analysis of phylogenetic relationships and genetic variation in the genus Lycopersicon. Theor. Appl. Genet. 80:437-448.

Muniyappa, V., S.H. Jalikop, A.K. Saikia, Chennarayappa, G.Shivashankar, A. Ishwara Bhat, and H.K. Ramappa. 1991. Reaction of Lycopersicon cultivars and wild accessions to tomato leaf curl virus. Euphytica 56:3741.

Padidam, M., R.N. Beachy, and C.M. Fauquet. 1995. Classification and identification of geminiviruses using sequence comparisons. J. Gen. Virol. 76:249-263.

Picó, B., M.J. Díez, and F. Nuez. 1996. Viral diseases causing the greatest economic losses to the tomato crop. II. The tomato yellow leaf curl virus-A review. Scientia Hort. 67:151-196.

Picó, B., M.J. Díez, and F. Nuez. 1998. Evaluation of whitefly-mediated inoculation techniques to screen Lycopersicon esculentum and wild relatives to tomato yellow leaf curl virus. Euphytica 101:259-271.

Pilowsky, M. and S. Cohen. 1974. Inheritance of resistance to tomato yellow leaf curl virus in tomatoes. Phytopathology 64:632-635.

Pilowsky, M. and S. Cohen. 1990. Tolerance to tomato yellow leaf curl virus derived from Lycopersicon peruvianum. Plant Dis. 74:248-250.

Polston, J.E. and P.K. Anderson. 1997. The emergence of whiteflytransmitted geminiviruses in tomato in the Western hemisphere. Plant Dis. 81:1358-1369.

Ramappa, H.K., V. Muniyappa, and J. Colvin. 1998. The contribution of tomato and alternative host plants to tomato leaf curl virus inoculum pressure in different areas of south India. Ann. Appl. Biol. 133:187-198. Saikia, A.K. and V. Muniyappa. 1989. Epidemiology and control of tomato leaf curl virus in southern India. Trop. Agr. 66:350-354.

SAS Institute, Inc. 1981. SAS for linear models. SAS Inst. Inc., Cary, N.C. Scott, J.W., M.R. Stevens, J.H.M. Barten, C.R. Thome, J.E. Polston, D.J. Schuster, and C.A. Serra. 1995. Introgression of resistance to whiteflytransmitted geminiviruses from Lycopersicon chilense to tomato, p. 357367. In: D. Gerling and R.T. Mayer (eds.). Bemisia 1995: Taxonomy, biology, damage control, and management. Intercept Ltd., Andover, U.K.

Tanksley, S.D., M.W.Ganal, J.P.Prince, M.C. de Vicente,M.W.Bonierbale, P. Broun, T.M. Fulton, J.J. Giovannoni, S. Grandillo, G.B. Martin, R. Messeguer, J.C. Miller, L. Miller, A. H. Patterson, O. Pineda, M.S. Röder, R.A. Wing, W. Wu, and N.D. Young. 1992. High density molecular linkage maps of the tomato and potato genomes. Genetics 132:11411160.

Vasudeva, R.S. and J. Samraj. 1948. A leaf curl disease of tomato. Phytopathology 38:364-369.

Vidavsky, F. and H. Czosnek. 1998. Tomato breeding lines resistant and tolerant to tomato yellow leaf curl virus issued from Lycopersicon hirsutum. Phytopathology 88:910-914.

Young, N.D. and S.D. Tanksley. 1989. RFLP analysis of the size of chromosomal segments retained around the $T m$-2 locus of tomato during backcross breeding. Theor. Appl. Genet. 77:353-359.

Zakay, Y., N. Navot, M. Zeidan, N. Kedar, H. Rabinowitch, H. Czosnek, and D. Zamir. 1991. Screening Lycopersicon accessions for resistance to tomato yellow leaf curl virus: Presence of viral DNA and symptom development. Plant Dis. 75:279-281.

Zamir D., I. Ekstein-Michelson, Y. Zakay, N. Navot, M. Zeidan, M. Sarfatti, Y. Eshed, E. Harel, T. Pleban, H. van Oss, N. Kedar, H.D. Rabinowitch, and H. Czosnek. 1994. Mapping and introgression of a tomato yellow leaf curl virus tolerance gene, $T y-1$. Theor Appl. Genet 88:141-146.

Zeidan, M., S.K. Green, D.P. Maxwell, M. Nakhla, and H. Czosnek. 1999. Molecular analysis of whitefly-transmitted tomato geminiviruses from Southeast and South Asia. Trop. Agr. Res. Ext. 1(2):107-115. 